\title{
CONSTRUCTION OF PUBLIC ROADS AT THE MEETING POINT OF DIFFERENT LEGISLATION SYSTEMS
}

\author{
Maria Hełdak', Elena Bykowa ${ }^{2}$ \\ 1 Wroclaw University of Environmental and Life Sciences, Department of Spatial Economy, ul. Grunwaldzka 55, \\ 50-357 Wrocław, Poland, e-mail: maria.heldak@upwr.edu.pl \\ 2 Saint-Petersburg Mining University, Department of Engineering Geodesy, Russia, e-mail: vilena@spmi.ru
}

Received: 2017.07 .07

Accepted: 2017.08.12

Published: 2017.11.01

\begin{abstract}
The study discusses the topic of transport accessibility in Poland and the Russian Federation. The authors have analysed the principles of acquiring land for the construction of public roads, network development and problems that accompany the development of national roads. Since the political transformation at the beginning of the 1990's, Poland and Russian Federation have been in the need of legislative changes that would facilitate the acquisition of land for road investments. The study presents the dynamic development of the national roads system in Poland, after the accession to the European Union, and improvement of the communication system in the Russian Federation.
\end{abstract}

Keywords: road density, development of transportation networks, public roads, Russian Federation, Poland

\section{INTRODUCTION}

Poland has been struggling with the problem of transport accessibility for a long time. In spite of numerous investments in this area, deficits in the system of road networks and international routes are still visible. This creates economic barriers and delays the development of the country. In the Russian Federation, transport accessibility also remains a serious problem, which is additionally amplified by extremely large surface area of the country.

Roads are a significant component of development bringing complex social, economic, and ecological impacts [Forman and Deblinger, 2000].

Road freight transport is still the main mode of transport both in Poland and Europe. Polish transport to the East is particularly important. On the one hand, due to the low fuel prices in Russia and the ability to increase profits, this transport is cost-effective, but on the other hand, it is characterized by a high risk, such as theft or lack of return loads [Lorenc and Więcek, 2014]. Poland's accession to the structures of the European Union had a significant influence on the reduction of differences in transport accessibility. Since then, Poland has benefitted from the opportunity to use EU subsidies and funding. The use of means from the European budget for infrastructural development forced the Polish government to take actions to provide legal regulations with respect to the preparation and realisation of investments. The main focus was the development and improvement of the national road network.

Proponents of smart growth commonly make several specific propositions about the relationships between transportation and land use: (1) building more highways will contribute to more sprawl, (2) building more highways will lead to more driving, (3) investing in light rail transit systems will increase densities, and (4) adopting new town planning strategies will reduce automobile use [Hendy, 2005].

The problems of regulatory support to road engineering are researched by such scientists as Gate [2011], Rymantsev [2012], Gryada [2013] and others. Theoretical and methodical aspects of making amends caused by withdrawal of nonstate land are presented in works of Nozdrachov [2015] 
and Obolonkova [2015]. Problems of new road construction and modernization of existing highways are mentioned in works of Smirnov and Telegin [2012] and others. A plenty of scientific studies confirm the topicality of the described theme.

The aim of the study is to discuss the theoretical aspects related to the acquisition of land for the purposes of road investments both in Poland and in the Russian Federation. The problems related to the acquisition of real property for the construction of public roads have been presented on the example of the $\mathrm{S}-8$ express road Wroclaw - Warsaw and Saint-Petersburg Ring Road, preceded by an analysis of the transformations in the road network basing on motorways and express roads.

\section{MATERIAL AND METHODS}

The data analysed in this study have been processed with the use of the statistical description and comparative analysis methods. The aim of the statistical description method is to summarize a set of data. This technique was used for the analysis of data concerning the length of realised roads and the costs of their construction. The collected data have been presented in a form of tables and visualised in a form of bar diagrams and pie charts.

The comparative analysis method is used to compare objects described with the use of numerous attributes. It is based on the analysis of relations between market data. This study employs the following comparative analysis techniques:

a) quantitative - based on statistical and graphic analysis of a set of data;

b) qualitative - consisting in a relative comparison of descriptive, non-measurable data.

The scope of the study was considered with respect to the following aspects:

1) Thematic scope - referring to the theoretical aspects of land acquisition for public roads and to the development of road networks in Poland and Russia;

2) Time scope covering the dynamics of changes in the transport infrastructure after 2003 in Poland and 2000 in Russia. For Poland, this refers to the period after the accession to the European Union with respect to motorways and express roads; For Russia this refers to period of land reform and transition to the market economy;

3) The geographic scope refers to the territories of Poland and the Russian Federation.

\section{ACQUISITION OF LAND FOR THE PURPOSES OF PUBLIC ROAD CONSTRUCTION}

The Act of April 10, 2003 on special rules for the preparation and implementation of public road investments (hereinafter referred to as "the Act on Public Road Investments"), specifies the principles and conditions for the preparation of road investments. The Act has been amended several times. Two most important amendments were introduced on December 16, 2006 and September 18,2008 . These dates mark the three stages of the process of land acquisition for the construction of public roads:

a) STAGE I - until December $16^{\text {th }}, 2006$;

b) STAGE II - from December $16^{\text {th }}, 2006$ to September $18^{\text {th }}, 2008$;

c) STAGE III - from September $18^{\text {th }}, 2008$ [Bełej and Walacik, 2009].

The first two methods were applied during the acquisition of land for the construction of roads of local territorial self-government units, and they were regulated by the provisions of the Act on Real Estate Management. As far as national roads were concerned, the procedure was different. In such cases, the provisions of the Act on Public Road Investments were applicable. The procedure of land acquisition was started by a decision on the determination of the location of the road, issued by the respective Voivode.

After the amendment, public roads were localised pursuant to the decision concerning the location of the road. The said decision was issued upon the request of the respective road operator. Decisions for national roads were issued by the Voivode, and for other roads - by the starosta. Such decisions specified the boundaries and confirmed the division of the real property [Źróbek and Walacik, 2008].

During Stage III, a new type of decision was introduced by the amendment to the Act - decision on the building permit for road works investment. This decision has replaced the decision on the location of the road and on the building permit.

Regulations introducing the decision on building permit for road works investment resulted in the replacement of five separate administrative procedures with a single procedure leading to an administrative decision. This decision combines:

a) the determination of the location of the road;

b) the confirmation of the division of real property;

c) expropriation of the real property; 
d) approval of the construction design and building permit;

e) limitations in the usage of adjacent real property [Trembecka, 2011; Hełdak, 2016].

The aim of the Act of April 10, 2003 on special rules for the preparation and implementation of public road investments was to simplify the road construction process. The initial provisions of the Act proved time consuming in practice, so the Act was amended. The amendments simplified the procedure of land acquisition for the realisation of public road investments, which in turn accelerated the process of constructing public roads.

In Russia, as in Poland land granting is inextricably connected with withdrawal. All land parcels are formally or practically involved in a particular sphere, each of them is owned and used by an individual person or state. Allotment of land for roads consists of land-use withdrawal planning and/or land granting for state and municipal needs. According to article №6 of Federal law of the Russian Federation of November 8, 2007 N257-FZ ,About roads and road activity in the Russian Federation and on amending in certain legislative acts of the Russian Federation", roads can be owned by the state, constituent entity of the Russian Federation, municipal authorities, natural person and a legal entity.

Land parcels withdrawal for road building purposes is performed on the basis of verdicts of: a) competent federal agencies (in cases of land withdrawal for objects of federal importance allocation);

b) competent executive authorities of the constituent entity of the Russian Federation (in cases of land withdrawal for objects of regional importance allocation);

c) local government authorities (in cases of land withdrawal for objects of local importance allocation).

Land withdrawal for state or municipal needs in aims of road building is considered acceptable, if it is spelt in land-use planning documents and/or approved by draft area plans. Otherwise it might be required by international agreements of the Russian Federation to withdraw land for international purposes. The main innovation in laws is that land could be withdrawn not only for construction of a new, but also for reconstruction of existing object of federal importance. Land Code establishes rights for natural monopolies, if the land parcel is planned for municipal or state aid roads or use of subsurface resources (article №56.4 of the Land Code of the Russian Federation). Innovations also provide opportunity to withdraw land at the request of organizations, which are on the special list. This list of organizations should be established by the Government.

A mechanism of withdrawal and land granting for federal and regional importance roads construction and reconstruction might be divided into the following steps:

- Filing of application for withdrawal to the competent executive authorities or to the local government agency.

- Revealing the persons whose real estates will be withdrawn using United State Register of Real Estate Rights and Transactions.

A legal owner of withdrawn land can ask to provide him another land parcel or real property or interest in it, which value will be applied towards loss recovery. Improvements in the Land Code detail objects, which are not taken into account in loss recovery. For example, a legal owner of parcel would not receive a refund for the construction, which has been built on land, in case if it does not match the permitted use. Losses incurred due to inability to perform lease contract of this land will not be compensated (Paragragh. 8 Article. 56.8 of the Land Code).

\section{DEVELOPMENT OF THE TRANSPORT NETWORK IN POLAND AND IN THE RUSSIAN FEDERATION}

After 2003 Poland accessed the European Union, and since 2004 a series of factors have occurred that stimulated the development of transport infrastructure in our country. Ten years of works resulted in the creation of a framework of modern road infrastructure in Poland. In 2013, the length of the motorways and express roads network was $2970 \mathrm{~km}$. This means an increase by $2339 \mathrm{~km}$. During more than 10 years, the length of motorways grew by $1112 \mathrm{~km}$, and of express roads - by $1227 \mathrm{~km}$.

In the years 2004-2013 in Poland modern road infrastructure was created and the quality of travelling by roads improved significantly. During 11 years, motorways and express roads of a total length of $2339 \mathrm{~km}$ were constructed (Table 1, Fig. 1) 


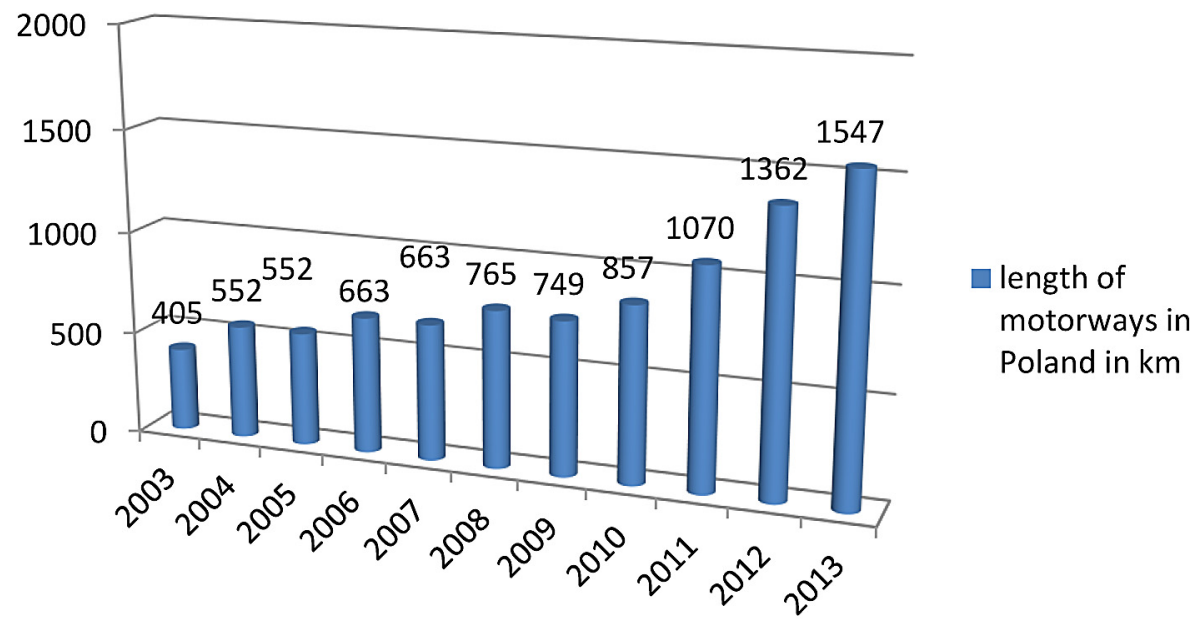

Fig. 1. Length of the motorways and express roads in the years $2003-2013$

Source: Own study based on data of the Polish Central Statistical Office.

Table 1. Length of motorways and express roads in the years 2003 and 2014

\begin{tabular}{|l|c|c|}
\hline \multirow{2}{*}{\multicolumn{1}{|c|}{ Item }} & \multicolumn{2}{c|}{ Road length $(\mathrm{km})$} \\
\cline { 2 - 3 } & 2003 & 2013 \\
\hline Motorways & 405 & 1517 \\
\hline Express roads & 226 & 1453 \\
\hline Total & 631 & 2960 \\
\hline
\end{tabular}

Source: Own study based on data of the Polish Central Statistical Office.

The total length of motorways in $\mathrm{km}$ in specific years is presented in the figure below (Fig. 1).

In comparison to other countries that accessed the European Union in 2004, Polish network of motorways was less developed than in the Czech Republic, Slovakia, Hungary or Slovenia. Currently Poland ranks much higher in this aspect. During the analysed period an increase in the density of motorways measured in $\mathrm{km}$ per $1000 \mathrm{~km}^{2}$ was noted (Table 2).

Pursuant to the annual Report on the Technical Condition of the road network in Poland [Radzikowski and Foryś, 2015] one may say that the condition of the national road network is varied, both in the aspect of total immediate needs and the needs connected with planned maintenance. One of the causes of this situation are the large differences in the load of the national roads network in individual voivodeships. Definitely the highest mean traffic load, exceeding 18000 vehicles/day was noted in the Silesian Voivodeship. In many other voivodeships (Małopolskie, Lodzkie, Lower Silesian, Masovian, Wielkopolskie) this load amounts, on the average, to approx. 11000 vehicles/day. On international roads the highest mean traffic load, exceeding, on the average, 35000 vehicles/day was noted in the Silesian Voivodeship.

Very high load of the international road network, exceeding, on the average, 20000 vehicles/ day, was noted in the following voivodeships: Opolskie, Małopolskie and Masovian [Synthesis of results... 2011].

According to reporting documents of Federal Road Agency, in 2015 the total length of highway in Russia was $512.8 \mathrm{~km}$ and the total length of speedways was $4573.4 \mathrm{~km}$. It is more than in 2014 on $37.9 \mathrm{~km}$ and $171 \mathrm{~km}$ respectively (table 3). That kind of classification was introduced in 2009. Table 4 presents the total length of roads in Russian Federation according to data on $1^{\text {st }}$ of January, 2015.

Table 2. Density of motorways per $1000 \mathrm{~km}^{2}$ in Poland in the years $2003-2013$

\begin{tabular}{|c|c|c|}
\hline \multirow{2}{*}{ Item } & \multicolumn{2}{|c|}{ Motorway density per $1000 \mathrm{~km}^{2}$} \\
\cline { 2 - 3 } & Year & Poland \\
\hline 1. & 2003 & 1.30 \\
\hline 2. & 2004 & 1.76 \\
\hline 3. & 2005 & 1.76 \\
\hline 4. & 2006 & 2.12 \\
\hline 5. & 2007 & 2.12 \\
\hline 6. & 2008 & 2.45 \\
\hline 7. & 2009 & 2.72 \\
\hline 8. & 2010 & 2.74 \\
\hline 9. & 2011 & 3.42 \\
\hline 10. & 2012 & 4.37 \\
\hline 11. & 2013 & 4.74 \\
\hline
\end{tabular}

Source: Own study based on data of the Polish Central Statistical Office. 
Table 3. Information About Road Categories in Russia

\begin{tabular}{|c|c|c|c|c|c|c|}
\hline & \multirow[b]{2}{*}{ Roads } & \multirow[b]{2}{*}{$\begin{array}{l}\text { Total Length of } \\
\text { Hard-surface } \\
\text { Roads }\end{array}$} & \multirow[b]{2}{*}{$\begin{array}{c}\text { Federal-aid } \\
\text { Highways }\end{array}$} & \multirow[b]{2}{*}{$\begin{array}{c}\text { Roads of Regional } \\
\text { and Intermunicipal } \\
\text { Importance }\end{array}$} & \multicolumn{2}{|c|}{ Roads of International Importance } \\
\hline & & & & & $\begin{array}{l}\text { "E" Category } \\
\text { Roads (Roads } \\
\text { of European } \\
\text { Importance) }\end{array}$ & $\begin{array}{l}\text { "AN" Category } \\
\text { (Roads of Asian } \\
\text { Importance) }\end{array}$ \\
\hline \multicolumn{2}{|c|}{ Measuring Unit } & $\mathrm{km}$ & $\mathrm{km}$ & $\mathrm{km}$ & $\mathrm{km}$ & $\mathrm{km}$ \\
\hline \multicolumn{2}{|c|}{ Total } & 519544.4 & 51522.9 & 468021.5 & 19735.6 & 16925.5 \\
\hline \multirow{7}{*}{ 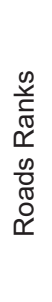 } & I -A Highways & 512.8 & 352.7 & 160.1 & 361.5 & 12.1 \\
\hline & I-B Speedways & 4573.4 & 3961.2 & 612.2 & 3355.1 & 1007.3 \\
\hline & I-B & 2390.5 & 1259.5 & 1131.0 & 752.4 & 562.3 \\
\hline & II & 34207.4 & 19933.5 & 14273.9 & 9658.5 & 7443.1 \\
\hline & III & 109769.8 & 19210.7 & 90559.1 & 5381.1 & 7347.9 \\
\hline & IV & 295237.2 & 5893.0 & 289344.2 & 225.6 & 528.6 \\
\hline & $\mathrm{V}$ & 72853.3 & 912.3 & 71941.0 & 1.4 & 24.2 \\
\hline
\end{tabular}

Source: Data of the Unified Interdepartmental Statistical Information System.

Table 4. Total Length of Highways and Speedways for the Period from 2000 to 2015

\begin{tabular}{|l|c|c|}
\hline \multirow{2}{*}{\multicolumn{1}{|c|}{ Item }} & \multicolumn{2}{c|}{ Road Length $(\mathrm{km})$} \\
\cline { 2 - 3 } & 2000 & 2015 \\
\hline Motorways & 106.4 & 512.8 \\
\hline Express roads & & 4573.4 \\
\hline Total & & 5086.2 \\
\hline
\end{tabular}

Source: Own study based on data of the Unified Interdepartmental Statistical Information System.

In Russia $406.4 \mathrm{~km}$ of highways have been built since 2000 (table 4). Dynamics of highways extension for the period from 2000 to 2015 in Russia shows fig. 3, 2.

According to summary data, 12 road segments in Russia are classified as highways (their details are presented in table 5 .

Closeness of hard-surface roads of federal, regional and intermunicipal significance (according to Federal Road Agency and Federal Service of State Statistics data) for the period from 2003 to 2014 is presented in the table 6 .

In 2014 there were $95.6 \mathrm{~km}$ more roads of federal significance put into operation comparing to 2013, as stated by Federal Road Agency. Also more than $581.7 \mathrm{~km}$ (88 objects) were put into operation. The total length of repaired roads was $9500 \mathrm{~km}$. It is 2.2 times larger than in 2012 . The new federal roads included such major objects as

- constructions of XXII Winter Olympic Games in Sochi;

- section of Moscow road junction (including second phase of a project of Dmitrov city bypass road) on the Moscow Outer Ring;

- section of a M-5 road ("Ural") between Moscow small ring and Ulyanino village;

- reconstructed section of M-9 road ("Baltic").
Within the territory of St.Petersburg road junction access road to commercial seaport "UstLuga" and highway interchange from St. Petersburg Ring road to abuilding seaport "Bronka" were put into work. At subsidy from federal budget expense were set to work $670.4 \mathrm{~km}$ of regional and municipal roads. As a result of activity of public road system in 2014 the total length of roads, which meet the standards, was $52.8 \%$.

Share of federal roads used in overload conditions was decreased from $26.4 \%$ (in 2013) to $23.4 \%$ (in 2014).

\section{PROBLEMS ACCOMPANYING LAND ACQUISITION FOR THE CONSTRUCTION OF NATIONAL ROADS}

By reason of the fact, that road construction (as well as other large infrastructure objects) goes hand in hand with land withdrawal from owners, land users, landlords, tenants, from time to time a conflict between interests could appear. It could be in situations, when initiator of withdrawal (authorities or candidate for land plot) is assessing estate insufficiently, and proprietor tries to defend their rights. Let us observe the projects of road construction in a frame of research on the example of S-8 (express road Wroclaw - Warsaw) and St. Petersburg Ring Road.

The S-8 express road is a road investment realised in Poland, in the territory of 5 provinces: Lower Silesian, Wielkopolskie, Lodzkie, Masovian and Podlaskie. The analysed area is limited to the Lodzkie Province. The analysed real properties acquired for the realisation of the construction of the S-8 road are located in the following 


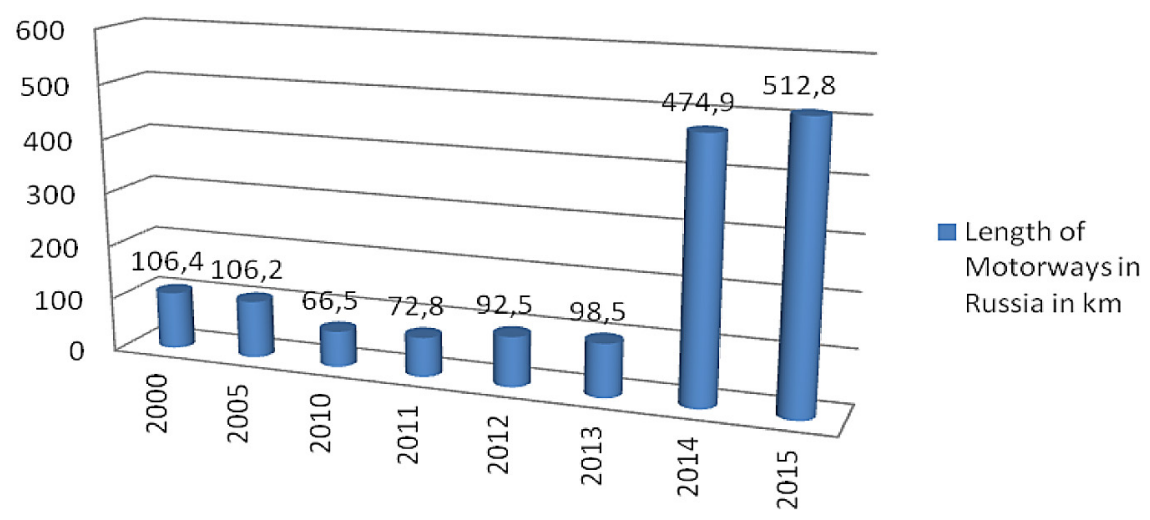

Fig. 2. Length of the Motorways in the Years 2000 - 2015

Source: Own study based on data of the Unified Interdepartmental Statistical Information System.

Table 5. Characteristics of Highways in Russia

\begin{tabular}{|c|c|c|c|}
\hline Name & Surface & Width. $\mathrm{m}$ & Closeness of Highways on $1000 \mathrm{~km}^{2}$ \\
\hline M2 & \multirow{12}{*}{$\begin{array}{l}\text { Bitumen } \\
\text { Concrete }\end{array}$} & $8-10$ & 0.0092 \\
\hline M4 & & $7-9$ & 0.0067 \\
\hline M5 & & $7-8$ & 0.0019 \\
\hline M7 & & 15 & 0.0018 \\
\hline M8 & & $7-8$ & 0.0011 \\
\hline M9 & & $7-8$ & 0.0058 \\
\hline M11 & & $15-37.5$ & 0.0069 \\
\hline Moscow Ring Road & & & 0.0003 \\
\hline St. Petersburg Ring Road A-118 & & $15-32$ & 0.0084 \\
\hline Western High-Speed Diameter & & 29 & 0.0020 \\
\hline P242 & & 22.5 & 0.0004 \\
\hline P384 & & No information available & 0.0026 \\
\hline Total & & & 0.0471 \\
\hline
\end{tabular}

Table 6. Closeness of Hard-surface Roads on 1000 $\mathrm{km}^{2}$ for the Period from 2003 to 2014

\begin{tabular}{|c|c|c|}
\hline \multirow{2}{*}{ Item } & \multicolumn{2}{|c|}{$\begin{array}{c}\text { Closeness of Hard-Surface Roads } \\
\text { on } 1000 \mathrm{~km}^{2}\end{array}$} \\
\cline { 2 - 3 } & Year & Russia \\
\hline 1. & 2003 & 32 \\
\hline 2. & 2004 & 32 \\
\hline 3. & 2005 & 31 \\
\hline 4. & 2006 & 35 \\
\hline 5. & 2007 & 37 \\
\hline 6. & 2008 & 37 \\
\hline 7. & 2009 & 38 \\
\hline 8. & 2010 & 39 \\
\hline 9. & 2011 & 43 \\
\hline 10. & 2012 & 54 \\
\hline 11. & 2013 & 58 \\
\hline 12. & 2014 & 60 \\
\hline
\end{tabular}

Source: Own study based on data of the Unified Interdepartmental Statistical Information System. poviats: sieradzki, zduńskowolski and łaski. This road has been assigned to the category of national roads, administrated by the General Director for National Roads and Motorways.

For the purposes of the construction of the S-8 road, the land was acquired pursuant to the provisions of the Act on special rules for the preparation and implementation of public road investments. In the years 2010 - 201211 motions were submitted to the Voivodeship Office in Lodz for the issuing of the decision on building permit for the roadworks investment consisting in the construction of S-8 express road (separately for each individual section of the road).

The decisions confirmed the division of land plots, separating the part situated within the boundaries of the investment area, which became the property of the State Treasury. The binding decision deprived the land located on the planned route of the road from ownership title. 
For the purposes of this study, comments filed to the issued decisions have been analysed. On the average, a total of 20 motions were filed for each decision issued for the planned course of the road. The most common issues raised in the comments included:

- lack of access road to the part of the land plot situated outside the boundaries of the investment area;

- requests to purchase the remaining parts of the plots that have been divided;

- lack of consent for the planned location of the planned rest areas for road users;

- replacement of the plot.

In most cases, the investor considered these motions as unjustified and did not take them into account in the design.

St. Petersburg Ring Road is a road of federal importance. It is passing through the territory of St. Petersburg and Leningrad Region. Building of St. Petersburg Ring Road helps to lessen the load of transit transport on the territory of the city and to reduce the impact on city environment. The issue of road around the Leningrad (old name of St. Petersburg) building was for the first time discussed in 1965, it was also mentioned in Site Plan of the city of that period. Implementation of the ring road started only in the late 1990's project. Today the total length of St. Petersburg ring road is $140.9 \mathrm{~km}$, including 26 road junctions, 106 bridges and viaducts, but it is not fully built yet. At each stage of the Ring road construction a plenty of problems have been appeared, which could be assorted to several directions:

- difficulties with land vacation, which are not in municipal or state property;

- time-consuming process of property redemption and document execution. According to the words of Vyachislav Petrushenko (at present time he is the chief of Federal institution "CentralAutoMagistral") expenditures not connected with road construction take about $20 \%$ of the total cost of road building, redemption of property takes about $12-13 \%$;

- problems connected with reengineering of general utilities. Damage of them may cause not only the problems in work of industrial enterprises, but even housing-and-municipal complex disturbance and even ecological collapse;

- problems with withdrawal coordination (payout period and amount of damages) from landlords, land-users, and tenants. The lack of agreement on the amount of the redemption price and losses from the legal owner of the land plot leads to delays in the timing of construction of the highway. For instance, during the construction of St. Petersburg Ring Road on several road section appeared the problem of redemption amount. Owners of land parcels and constructions on them demanded 20 million roubles, while appraisal cost of it was only 2 million roubles (Strigin 2010).

- problems, caused by legislation imperfection in procedures of dwellings resettlement. For example, in a zone of St. Petersburg Ring Road construction two houses were situated at the intersection of Volhonsky and Tallinn highways. These houses were related to Leningrad Region, but most of dwellers had residence permit in St. Petersburg. In a view of the fact that the protocol for liaison between two public authorities is not clearly described, work was regulated in a court case.

\section{CONCLUSIONS}

The above discussion on the theoretical aspects of the acquisition of real property for the purposes of public roads construction and the analysis of the process of obtaining land for public roads has allowed us to formulate the following conclusions:

1. Before 2004, the national roads network in Poland was poorly developed, which was reflected in low density of national roads and motorways. Considering the international transit nature of our country, the development of the road network required development.

2. Currently, land for the purposes of the construction of express roads is acquired pursuant to "special legislation" that facilitates the realisation of road investments. The procedure, which generally consists in the expropriation of real property, has significantly accelerated the expansion of the motorways and express roads network in Poland and Russia.

3. The protection of interest of the owners of land plots located in the planned course of national roads leaves much to be desired. Most of the comments submitted during the process of issuing the decision on building permit for roadworks investment are not taken into account at all. 
4. The issue of protecting the interest of the owners of land plots located in the area of the planned course of the road, as well as environmental protection issues are important consequences of the roadwork investments and, as such, they should be the subject of further analysis of the effects of the road system development.

5. Outstanding matters connected with road design and construction in Russia require making changes into "Transport Strategy", including problems of new technologies adaptation and transport projects financing growth.

6. Road construction is a time-consuming process. There are times, when construction of a road is lasting for decades. During this time law changes, resulting non-identity of methods of withdrawal, loss indemnity, and land granting.

7. Realization of public roads construction projects using reservation of land let reduce time spending on withdrawal implementation on the basis of real property buy-back.

8. In Russia law stipulates, that compensation of losses could be expressed in a form of equal land plot (market value of withdrawn and provided land parcels should be flat). However, there is no information in law about geographical conditions of provided land plot. In that way, the owner of a land on the lakeside as a compensation of losses caused by withdrawal could receive a larger parcel in a field or the owner of garage near his house would be offered to get land at a considerable distance.

\section{REFERENCES}

1. Bełej M., Walacik M. 2009. Evolution of the procedures of land acquisition for the purposes of road construction and the contract balance principle. Real Estate Management and Valuation, Studia i Materiały Towarzystwa Naukowego Nieruchomości, vol.17, No. 4/2009, 83. (in Polish)

2. Cai X., Wucd Z., Chenge J. 2013. Using kernel density estimation to assess the spatial pattern of road density and its impact on landscape fragmentation', International Journal of Geographical Information Science 27(2):2013.

3. Federal law of the Russian Federation of November 8, 2007 N257-FZ About roads and road activity in the Russian Federation and on amending in certain legislative acts of the Russian Federation.

4. Federal Statistic Service Available at: http://cbsd. gks.ru/\# (Accessed at 05/02/2015)
5. Forman, R.T.T, Deblinger, R. 2000. The ecological road-effect zone of a Massachusetts (USA) suburban highway', Conservation Biology, 14 (1), $36-46$.

6. Gate N.A. 2011. Features of land grantig for building aims. Нотариус, Издательская группа «Юрист». Moscow. (in Russian)

7. Government Decree of December 28, 2012 №2600-p ,About Programm of ,Transport Development" approval".

8. Gryada E.A. 2013. Land reservation as a reason of deny of land granting into private property. Вестник омского университета им. Ф.М. Достоевского. Серия: Право, Омский государственный университет им. Ф.М. Достоевского,. Omsk, No. 2(35), 2013. pp. 54-57. (in Russian)

9. Handy S. 2005. Smart Growth and the Transportation-Land Use Connection: What Does the Research Tell Us?, International Regional Science Review, April 2005; vol.28, 2: pp. 146-167.

10. Hełdak M. 2016. The principles of land acquisition for public roads in Poland. Prace aukowe Uniwersytetu Ekonomicznego we Wrocławiu, No 418, 107-116.

11. Info-Statistical Bulletin of Department of Transportation. 2014. Moscow.

12. Lorenc A., Więcek P. 2014. Safety and Effectiveness of Road Cargo Transport Between Poland and Russia, Technical Transactions. Mechanics, $1-\mathrm{M} / 2014$.

13. News Page of Department of Transportation of the Russian Federation. 8 May of 2014. Available at: http://www.mintrans.ru/news/detail.php?ELEMENT_ID=22121 (Accessed at 05/02/2015).

14. Nozdrachov V.A. 2015. Several historical aspects of withdrawal and valuation of land for railways construction. Изв. вузов «Геодезия и Аэрофотосъемка», No.5. 2015. Moscow. pp.43-47. (in Russian)

15. Obolonkova E.V. 2015. Land withdrawal for federal needs: problems of compensation paid to private landowners. Законодательством и экономика, Изд. «Законодательство и экономика». No. 1. 2015. Moscow. pp. 68-73. (in Russian)

16. Rymantsev F.P. 2012. Legal regulation of agricultural land turnover: theoretical and practical questions. Doct. Diss. Moscow. 2012. 401 p. (in Russian)

17. Smirnov V.G., Telegin V.A. 2012. Development of the mechanism of regional communal infrastructure modernization and evolvement. Региональная экономика: теория и практика, ООО «Издательский дом ФИНАНСЫ и КРЕДИТ», Moscow, 2012. no.1. pp. 2-6. (in Russian)

18. Strigin A.G. 2012. Fit in with the company. North- 
ern capital of Russia got a new arterial street. Российская газета. No.235 (5314). 2010. Pp.4. (in Russian)

19. Radzikowski M., Foryś G., 2015. 'Report on the Technical Condition of the road network in Poland for the end of 2014', General Directorate for National Roads and Motorways, Warsaw. (in Polish)

20. Regulation of the Minister of the Regional Development and Infrastructure, dated March 29, 2001, on the register of plots of land and buildings (Journal of Laws No. 38/2001, item 454)

21. Synthesis of the GPR results 2010, Transprojekt - Warszawa sp. z o.o., Warszawa 2011.

22. State National Report on the Status and Use of Land in the Russian Federation in 2013. Available at: https://rosreestr.ru (Accessed at 05/02/2015)

23. Transport System Development (2010-2020). Available at: http://rosavtodor.ru/activity/pokazateli-prognozy/14348.html (Accessed at 5/02/2015)

24. Trembecka A., 2001. One decision instead of five. Magazyn Geoinformacyjny Geodeta No. 11, November 2011, pages $39-40$.

25. United Statistical Information System. Available at: http://www.fedstat.ru/indicators/search.do (Accessed at 05/02/2015)

26. Źróbek S., Walacik M., 2008. The issues related to land acquisition for road investment purposes. Studia i Materiały Towarzystwa Naukowego Nieruchomości, Real Estate Management and Valuation, vol.16, No. 1/2008, page 95 (in Polish) 